\title{
Urban planning of the resort infrastructure in modern conditions
}

\author{
Alla Baranova ${ }^{1, *}$, and Svetlana Kegeyan ${ }^{1}$ \\ ${ }^{1}$ Sochi State University, Sovetskaya st., 26a, 354000, Sochi, Russia
}

\begin{abstract}
In tsarist Russia during the Soviet period and till now the resort is recognized as a locality with curative factors. However, in recent years, tourists visit resorts more for the purpose of rest than for recovery. The number of health resorts is decreasing but the number of hotels is increasing. Due to neglect of the medical component in the resort the epidemiological and infectious tension is increasing. In this article on the example of the resort city of Sochi the characteristics of urban planning of the resort infrastructure are given taking into account the customer focus and the need for the development of medicine in the resort. Keywords: urban planning, resort infrastructure, customer focus
\end{abstract}

\section{Introduction}

The history of the development of the resort infrastructure in Russia began at the beginning of the 18th century under the reign of Peter the Great when on his return from Europe in 1717 he issued a decree "On the Mineral Waters Search in Russia". The first resort of Russia - Marcial Waters arose in 1719 near Petrozavodsk. In the 1820-30's the birth of future resorts of the Caucasus began. In those days the resort meant "the presence of a natural source (mineral waters, therapeutic muds, etc.), a park for walking and apartment houses which were rented by vacationers" [1, p. 33].

By the beginning of 1940 there were 3,600 health-resort organizations and rest homes in the USSR with 470,000 seats. New resorts were created in the Urals, Siberia, the Far East. By the mid-1980s there were 14 thousand health-resort organizations for 2.5 million people in Russia. Powerful agglomerations were created: Greater Sochi, Big Yalta, Caucasian Mineral Waters. But the transition of the Russian economy to market relations (after 1991) led to the loss of many health resorts. In 2015 there were 3,689 health-resort organizations for 680,000 people [2]. Thus, at present the indices of resorts by the number of health resorts have approached the pre-war period. In this connection the question of the survival of resort towns arises, new ways of customer focus are needed.

\section{Methods}

As a result of the research the following methods of analysis, logic, generalization and systematization of scientific research were used. Statistical analysis and study of relevant

\footnotetext{
${ }^{*}$ Corresponding author:
} 
legislative acts ensured the reliability of the conducted research and validity of the conclusions. The characteristics of infrastructure, architecture and urban planning in the resorts are presented on the basis of the works of Bulatova EK, Ulchitsky OA, Zherebilo NV, Oborina MS, Vetitneva AM. etc. The need of improving the medical component of the resort infrastructure is determined by studying the works of Bruchanova GD, Bryukhanov AF, Zavor DL. and etc.

\section{Results}

In accordance with the Federal Law "On Natural Health Resources, Medical-Recreational Areas and Resorts" of 02/22/1995 N 26-FZ, a resort means a specially protected area that has been developed and used for medical and preventive purposes which has natural medical resources and is necessary for their buildings and structures operation including infrastructure [3]. In view of resort management authorities area of responsibility resorts are divided into federal, regional and local ones.

A similar division and special status of resorts was emphasized during the Soviet period. In 1970 for the most rational use of resort areas medical facilities and resort factors, elimination of shortcomings in the construction of resorts and recreation areas, improving of health-resort construction, the Council of Ministers of the USSR decided [4]:

1. To establish the division of resorts into resorts of all-Union, republican and local significance. The resorts of the Black Sea coast of the Krasnodar Territory, Caucasian mineral waters, Belokurikha, the resort zone of Leningrad on the coast of the Gulf of Finland, Shmakovka in the Primorsky Territory had all-Union significance.

2. To prohibit the construction of new and expanding industrial enterprises and other facilities at resorts not related to meeting the needs of the population and tourists directly. The construction of industrial enterprises and other facilities can be carried out as an exception at resorts of all-Union significance with the permission of the Council of Ministers of the USSR.

3. It is necessary to recognize that construction of health-resort organizations, rest homes, boarding houses and recreation centers should be carried out mainly with large complexes that are economical in construction and operation. In designing and building resort complexes the best domestic and foreign experience should be taken into account, a high level of architecture, construction quality, engineering equipment and facilities must be ensured and modern construction and finishing materials must be used.

4. The State Committee for Civil Construction and Architecture, ministries and departments of the USSR should approve the list of design organizations that must perform work on the planning and development of resorts as well as the design of resort organizations.

We have studied characteristics of infrastructure, architecture and urban planning in the resorts on the basis of the works of Bulatova EK, Ulchitsky OA, Zherebilo NV, Oborina MS, Vetitneva AM. and etc.

Bulatova E.K. and Ulchitsky OA made a research of the integrated approach to the organization of the functional and planning structure of tourist and recreational areas during the period of mass tourism in the USSR in 1920-1980 summarizing the experience of Soviet design practice on the basis of cities with a rich historical and architectural heritage [5]. They divided complex approach to the organization of the architectural environment of tourism into 4 periods.

The first period (1920-1940s.) was characterized by the idea of the foundation of the citygarden. The concept proposed the zonal division of urban areas into industrial, recreational and sleeping areas. This emphasized the recognition of the organizations of recreation and tourism as a city-forming sphere. Projects of city-gardens of Sergeevo-Kamenka in 
Petrograd, a garden city at Prozorovskaya station in Moscow, villages near Samara, Losinoostrovsky village, etc. were implemented.

The second period (1950 - early 1960's.). Since the 50's. XX century the geography of tourist and recreational areas is significantly expanding. The construction of mass recreation facilities in large industrial regions of the Urals, Siberia and the Far East began. Moreover, tasks for the defining of recreational areas, transport accessibility and organization of the maintenance infrastructure were set.

The third period (1960 - 1970's.). In Russia as in the rest of the world the trend of creating tourist research centers based on historical cities began. For example, a design institute for the model and experimental constructional design of health-improving and health resort-andspa buildings was established in Moscow in 1964. Its project department was engaged in experimental, typical and individual design of recreation facilities, treatment and tourism. The main tasks were:

- preservation of valuable architectural and artistic heritage;

- ensuring the active tourist life of the city.

- application of the "thematic complexes" method in the system of routes within tourist centers.

The fourth period (1980's.). During this period there is a rapid development of tourist centers at the expense of the natural environment. Priority tasks of the given period were:

- creating conditions for the year-round operation of recreational facilities;

- the formation of a single aesthetic architectural and artistic tourist environment.

Zherebilo N.V. paid attention to four main methods of organization and interconnection of all premises in the construction of compositions of a complex of health-resort organizations [6].

Centralized reception in which all groups of premises except for the economic one, are located in the same building. This provides a convenient connection of groups of rooms in all seasons of the year. The shortest paths between the rooms are convenient for service personnel, and for recreators.

The blocking of buildings in which the main groups of premises - sleeping, food, cultural services and medical - are located in separate buildings, connected with each other by transitions. Connecting blocks with transitions creates a convenient connection preserving the isolation of groups of rooms.

Pavilion scheme is a scheme where the main groups of premises are located in unconnected, separate buildings-pavilions. The advantage of the composition is the maximum approximation of the holidaymakers living in separate houses to the natural environment. However, this method requires a significant extension of communication links and engineering networks so it is uneconomical.

A mixed scheme is a combination of the three previous ones in varying degrees of their combination.

Accepted composite reception affects the cost of building a health-resort organization. The most economical (for all other equal conditions) are centralized compositions, then blocked, and the least economical -is a pavilion. Every device seldom exists in its pure form.

In general, the resort area includes the following components:

- the traditional urban infrastructure, without which it is impossible to operate any municipal entity (housing and communal services, transport and communications, health organizations, culture, credit organizations, etc.);

- specific, represented by a specific branch of specialization: for agriculture - land and plantations; for industry - specific structures, machinery, transfer devices; for transport rolling stock; for tourist industry - recreation, health prevention, accommodation facilities, sightseeing facilities.

Table 1 provides a description of the resort's infrastructure. 
Table 1. Characteristics of the infrastructure approach to the study of the resort.

\begin{tabular}{|l|l|}
\hline \multicolumn{1}{|c|}{ Authors } & \multicolumn{1}{c|}{ Description } \\
\hline $\begin{array}{l}\text { Fedorov VN, } \\
\text { Kazarin V.N. [7.8] }\end{array}$ & $\begin{array}{l}\text { The authors understand the term infrastructure as a hierarchically organized } \\
\text { complex of organizationally separate economic units and their main purpose } \\
\text { is to provide and maintain the activities of the basic branches of material } \\
\text { production and non-productive sphere }\end{array}$ \\
\hline Bogdanov A.V. [9] & $\begin{array}{l}\text { Infrastructure is a complex economic category that is a subsystem of a market } \\
\text { economy and includes a set of organizations, links between them and } \\
\text { institutional conditions that ensure the implementation of certain types of } \\
\text { activities, processes and procedures that meet the specific needs of individuals } \\
\text { and legal entities promoting competition and the smooth functioning of the } \\
\text { market economy }\end{array}$ \\
\hline $\begin{array}{l}\text { Sharafanova EE, } \\
\text { Morozov M.A. }\end{array}$ & $\begin{array}{l}\text { Infrastructure is a set of conditions (technical, technological, socio-economic, } \\
\text { organizational), providing a favorable development of entrepreneurial } \\
\text { activities in the economy and satisfying the needs of the population }\end{array}$ \\
\hline $\begin{array}{l}\text { Vetetnev AM, } \\
\text { Zhuravleva LB }\end{array}$ [12,p. 516] & $\begin{array}{l}\text { The resort infrastructure is "a system of material objects and activities that } \\
\text { provide resort services to the population and contribute to strengthening its } \\
\text { health" }\end{array}$ \\
Oborin M.S. [13,p. & $\begin{array}{l}\text { "Health-resort organization infrastructure is a set of objects of material and } \\
\text { social activity of a person that form under certain conditions (natural, } \\
\text { historical, cultural, socio-economic) the basis for stable and sustainable } \\
\text { functioning and development of health-resort activities in a particular territory } \\
\text { located in a place different from permanent residence, where between } \\
\text { vacationers, personnel, economic and medical facilities, as well as natural } \\
\text { healing resources form information and material and energy flows, aimed at } \\
\text { improving the quality of public health and meet the needs in the proper rest " }\end{array}$ \\
\hline
\end{tabular}

The peculiarity of the urban infrastructure of the resort city is that the number of tourists is several times greater than the number of local people usually in the season. As a result, the burden on the entire infrastructure of the municipality is greatly increased. Figure 1 shows the difference in the population by the example of a resort of federal significance - Sochi.

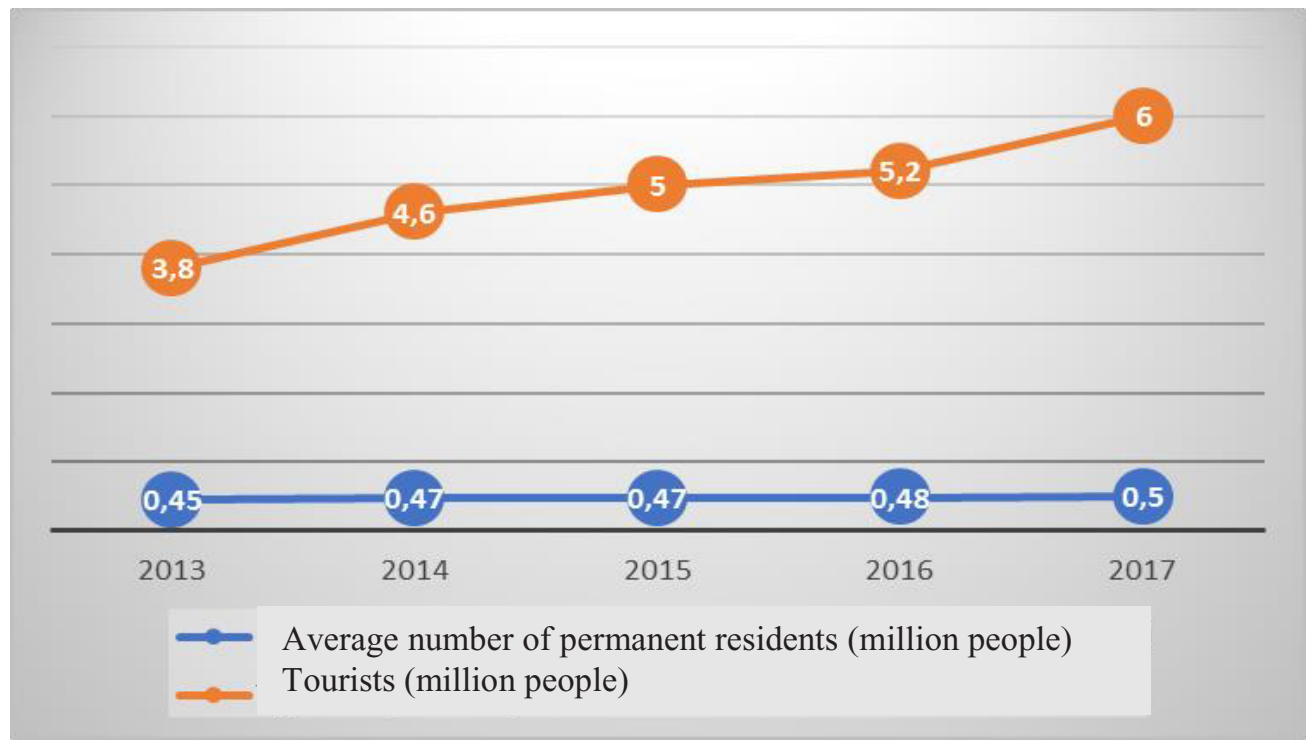

Fig. 1. The population of the city-resort of Sochi for the period 2013-2017 [14, 15].

We can draw conclusions about the difference between the local population of Sochi and tourists in 12 times. 


\section{Discussion}

On the basis of the presented theoretical analysis we come to the conclusion that the organizations of the tourist and recreational sphere in the resort form a city-forming branch. From the point of view of urban planning, point resorts were created from the very beginning (1719-1940) then tourist-and-recreational agglomerations (1950-1990) were formed and since 1991 till now there is a reduction in the number of health resorts, unprofitable budgets of resort towns, reduction of state support of resorts. Currently the main purpose of visiting resorts is a rest $-60 \%$ of tourists, recovery $-20 \%$ of tourists, professional activities $-12 \%$, other goals - $8 \%$ of tourists [16]. The least modern tourists consider resorts as medical places. They are more interested in historical places, cultural monuments, karaoke clubs, show programs, sports, folk crafts and national cuisine.

As people are traveling to the resort for different goals nowadays there is a need for urban planning taking into account the cluster approach, that is, the concentration in one microdistrict of organizations with complementary and interrelated functions. The cluster approach allows to distribute tourists on interests, that is to carry out segmentation. For example, coastal and mountain clusters function successfully in Sochi. The coastal cluster occupies the territory of Adler and Imeretinskaya lowland along the Black Sea coast, the central object of which is the Olympic Park, which includes sports facilities, hotels, transport infrastructure and a park area. The mountain cluster is located in the Krasnaya Polyana microdistrict. It includes complexes for sports competitions in winter sports, the center "Rosa Khutor", the complex "Russian Hills". All buildings in the Olympic mountain cluster have a single architectural appearance including private and residential buildings [17].

The city of Sochi is the only municipal formation in Russia located in the subtropical zone aimed at the development of agro-tourism. The agrarian sector of the city is represented by tea-growing and fruit growing branches, specialized organizations for the cultivation of trout, poultry, quail farm products, beekeeping and floriculture. The development of the agroindustrial complex of the city of Sochi is envisaged in the following areas: the construction of greenhouse complexes for vegetable production, the development of the tea industry, fish farming and aquaculture, the creation of new agro-tourist routes and the establishment of gardens [18].

As the city-resort is a place of a large congestion of people it is associated with a high risk of skidding and the spread of infectious diseases. A large number of factors that determine epidemiological risks require thorough advance preparation, application of innovations and modern technologies in the field of health prevention. In addition, medical contraindications to certain factors of the terrain are possible, for example, prolonged exposure to the sun, high humidity, etc. When people plan to go on vacation to a health-resort organization for the purpose of recovery they pass a medical examination in their city in advance, where they receive certain recommendations. People who stay at the hotel do not suspect that they are subject to the negative influence of the resort's natural factors.

Therefore topical tasks at the resort are not only the reconstruction of sights, the improvement of transport, communications, consumer services but there is a need for the development of science of balneology, medical support in all accommodation facilities. It is necessary to carry out a number of environmental measures: construction of wastewater treatment plants, sewerage facilities, new treatment facilities and a biological waste disposal complex, shore protection works, reproduction of mineral resources, landscaping of resort towns, development of a system of integrated environmental monitoring in order to monitor the condition environment and the like. If the resort city is conditionally divided into tourist clusters each of them requires a resort clinic where you can get emergency medical care for sudden illnesses, poisonings and injuries. 


\section{Conclusions}

Today the city of Sochi is a multifunctional resort. Great opportunities for summer holidays, new ski resorts, medical factors, event events - all these factors allow the city to be clientoriented and a benchmark for other tourist destinations. Even during the preparation for the Olympic and Paralympic Games - 2014, measures were provided to reduce epidemiological tension by means of construction of new infectious hospitals $[19,20]$. However, the millions of tourists should be satisfied not only with the quality of tourist and recreational services but also with timely medical assistance. Therefore, in the urban planning of the resort infrastructure it is necessary to provide a sufficient number of medical institutions.

\section{References}

1. A.V. Borisova, Y.Y. Ierusalimskij, Sovremennye problemy servisa i turizma 3 (2009) https://cyberleninka.ru/article/n/istoriya-razvitiya-sanatorno-kurortnogo-dela-v-rossii

2. Rosstat, http://www.gks.ru/free_doc/doc_2017/rusfig/rus17.pdf

3. Federal'nyj zakon ot 23.02.1995 № 26 - FZ

4. Postanovlenie Sovet Ministrov SSSR ot 28.08.1970g. №723, https://ipravo.info/sssr1/laws82/177.htm

5. E.K. Bulatova, Arhitekton: izvestiya vuzov 43 (2013) http://archvuz.ru/2013_3/9

6. N.V. Zherebilo, Arhitekton: izvestiya vuzov 21 (2008) http://archvuz.ru/2008_1/

7. V.N. Fedorov, Social'no-ehkonomicheskij potencial infrastruktury: soderzhanie, ocenka $i$ analiz razvitiya (UlGPU, Ul'yanovsk, 2000)

8. V.N. Kazarin, Strategiya razvitiya social'no-ehkonomicheskoj infrastruktury severnogo goroda: avtoref. (Moscow, 2007)

9. A.V. Bogdanov, Organizacionno-ehkonomicheskie osnovy razvitiya uslug regional'noj rynochnoj infrastruktury: avtoref. (Moscow, 2008)

10. E.E. Sharafanova, Strategicheskoe planirovanie razvitiya hozyajstvuyushchih sub"ektov $v$ sfere turizma: dis. (SPb, 2005)

11. M.A. Morozov, Infrastrukturnoe obespechenie predprinimatel'skoj deyatel'nosti $\mathrm{v}$ turizme: dis. (SPB, 2006)

12. A.M. Vetitnev, Kurortnoe delo: uchebnoe posobie (KNORUS, Moscow, 2006)

13. M.S. Oborin, Nauchnye vedomosti Belgorodskogo gosudarstvennogo universiteta. Seriya: EHkonomika. Informatika 19(216) (2015)

14. Social'no-ehkonomicheskoe razvitie goroda Sochi, https://www.sochi.ru/zhizngoroda/ekonomika/sots-ekon-razv-sochi

15. Koncepciya razvitiya sanatorno-kurortnogo i turistskogo kompleksa Krasnodarskogo kraya do 2030 goda

16. URL : https://www.kakprosto.ru/kak-257169-chto-predstavlyayut-soboy-gornyy-ipribrezhnyy-klastery\#ixzz5HFIQnuvG

17. URL : https://www.sochi.ru/zhizn-goroda/apk/

18. V.N. Gorodin, G.D. Bryuhanova, D.L. Zavora, et.al. Mezhdunarodnyj zhurnal ehksperimental'nogo obrazovaniya 11-6, 818-822 (2015)

19. G.D. Bryuhanova, Materialy VIII mezhdunarodnoj nauchno-prakticheskoj konferencii "Olimpijskoe nasledie i krupnomasshtabnye meropriyatiya: vliyanie na ehkonomiku, ehkologiyu i sociokul'turnuyu sferu prinimayushchih destinacij», 157 - 161 (2016) 